\title{
Penerapan Model Pembelajaran Team Assisted Individualization dengan Strategi Pembelajaran Tugas dan Paksa terhadap Kemampuan Pemecahan Masalah Matematika
}

\author{
Leonard $^{1 *}$, Kurnia Khaerul Nisa ${ }^{2}$ \\ ${ }^{1,2}$ Universitas Indraprasta PGRI \\ *leo.eduresearch@gmail.com
}

Diterima: Nopember 2019. Disetujui: Desember 2019. Dipublikasikan: Januari 2020.

\begin{abstract}
ABSTRAK
Penelitian ini dilakukan untuk mengetahui pengaruh model pembelajaran team assisted individualization dengan strategi pembelajaran tugas dan paksa terhadap kemampuan pemecahan masalah matematika. Kemampuan pemecahan masalah matematika merupakan salah satu tujuan pendidikan nasional di Indonesia, tetapi pencapaiannya masih tergolong rendah. Metode yang digunakan dalam penelitian ini adalah metode kuasi eksperimen dengan desain penelitian posttest-only. Pengambilan sampel pada penelitian ini menggunakan teknik purpose sampling. Sampel penelitian sebanyak 60 peserta didik yang terbagi dalam dua kelas (30 kelas eksperimen dan 30 kelas kontrol). Penelitian ini dilakukan di sekolah SMP N 10 Bekasi dan SMP N 26 Bekasi. Kelas eksperimen menggunakan model pembelajaran team assisted individualization dengan strategi pembelajaran tugas dan paksa, sedangkan kelas kontrol menggunakan pembelajaran langsung. Data yang terkumpul kemudian dianalisis dengan menggunakan uji beda rata-rata sampel bebas. Hasil analisis data menunjukan bahwa rata-rata nilai peserta didik yang pembelajarannya menggunakan model pembelajaran team assisted individualization dengan strategi tugas dan paksa lebih tinggi dibandingkan dengan rata-rata nilai peserta didik yang pembelajarannya menggunakan model pembelajaran langsung.
\end{abstract}

Kata kunci: model pembelajaran team assisted individualization, strategi pembelajaran tugas dan paksa, kemampuan pemecahan masalah matematika.

\section{ABSTRACT}

This research was conducted to determine the effect of team assisted individualization learning models with task learning strategies and forced to the ability to solve mathematical problems. Mathematical problem solving ability is an ability that belongs to the national education goals, but its achievement is still relatively low. The method used in this study is a quasi-experimental method with a poststest-only research design. Sampling in this study uses purpose sampling technique. The study sample consisted of 60 students divided into two classes (30 experimental classes and 30 control classes). This research was conducted in the school of SMP N 10 Bekasi and SMP N 26 Bekasi. The experimental class uses team individualization learning models with task and forced learning strategies, while the control class uses direct learning. The collected data is then analyzed using independent sample ttest. The results of data analysis showed that the average value of students who learned using the team assisted individualization learning model with higher task and forced strategies compared to the average value of students who learned using direct learning models. Keywords: Team assisted individualization learning model, task and forced learning strategies, mathematical problem solving skills

How to Cite: Leonard, \& Nisa, K. K. (2020). Penerapan Model Pembelajaran Team Assisted Individualization dengan Strategi Pembelajaran Tugas dan Paksa Terhadap Kemampuan Pemecahan Masalah Matematika. Journal of Medives: Journal of Mathematics Education IKIP Veteran Semarang, $4(1), 111-127$. 


\section{PENDAHULUAN}

Pendidikan merupakan faktor yang sangat penting dalam mempengaruhi perkembangan individu untuk menciptakan masyarakat yang mempunyai daya saing di segala bidang. Menurut Dacholfany (2016) pendidikan merupakan proses kegiatan mengubah pelaku individu ke arah kedewasaan dan kematangan, sehingga dengan adanya pendidikan diyakini dapat melakukan perubahan-perubahan dalam kehidupan manusia ke arah yang lebih baik, benar, bermanfaat dan terencana. Pendidikan adalah usaha sadar dan terencana untuk mewujudkan suasana belajar dan proses pembelajaran agar peserta didik secara aktif mengembangkan potensi dirinya untuk memiliki kekuatan spiritual keagamaan, pengendalian diri, kepribadian, kecerdasan, akhlak mulia, serta keterampilan yang diperlukan dirinya, masyarakat, bangsa dan negara (Afandi \& Sidoarjo, 2011). Rendahnya kualitas pendidikan merupakan sebab dari kurangnya sumber daya manusia yang berkualitas, sehingga terhambatnya pembangunan di Indonesia. Hal ini sependapat dengan Kusuma \& Subkha (2015) bahwa Negara Indonesia sebagai negara berkembang sangat membutuhkan sumber daya manusia yang berkualitas. Salah satu usaha untuk menciptakan sumber daya manusia yang berkualitas adalah melalui pendidikan.

Bagian terpenting dalam pendidikan adalah proses pembelajaran. Pembelajaran yang bermakna dapat meningkatkan hasil belajar peserta didik dan dapat mengembangkan potensi yang ada didalam diri peserta didik. Hal ini dipertegas oleh Laurillard (Neo, Lim \&
Lim, 2013:39) bahwa "the learning process must consist of a combination of discursive, adaptive, interactive and reflective activities to effectively engage students in deep meaningful learning". Pembelajaran bermakna adalah tujuan utama dalam proses pembelajaran untuk mencetak generasi penerus bangsa yang berkualitas. Kurikulum 2013 yang berlaku saat ini mengharuskan terjadinya pembelajaran yang bermakna. Hal ini dipertegas oleh Yasir \& Ibrahim (2011) bahwa kurikulum 2013 sarat akan pengimplementasian paradigma pembelajaran dan penilaian yang bercirikan, (1) peserta didik adalah subjek dalam belajar, (2) peserta didik diminta untuk selalu bernalar dalam belajar dengan tuntutan berpikir tingkat tinggi (higher order thinking) pada level C4, C5, dan C6, dan (3) pembelajaran yang bermakna. Namun, pada kenyataannya berdasarkan pengamatan di beberapa sekolah, hampir seluruh sekolah pembelajarannya masih berpusat pada guru. Artinya, pembelajaran hanya terpaku dengan apa yang disampaikan oleh guru dan kurang terkait dengan kehidupan sehari-hari peserta didik. Hal ini menunjukan bahwa pembelajaran saat ini masih sangat jauh dari kurikulum 2013.

Dalam dunia pendidikan, matematika adalah salah satu cabang ilmu yang sangat penting. Karena pentingnya, matematika diajarkan dari mulai jenjang SD sampai perguruan tinggi. Ini merupakan wujud nyata bahwa matematika sangat dibutuhkan dalam kehidupan sehari. Matematika adalah ilmu dasar yang sangat erat dengan kehidupan sehari-hari yang membutuhkan nalar untuk menyelesaikannya. Menurut Ramlan 
(2013) matematika dapat menata nalar, membentuk kepribadian, menanamkan nilai-nilai, memecahkan masalah, dan melakukan tugas tertentu. Dengan mempelajari matematika dengan baik dapat membuat peserta didik memecahkan setiap masalah yang terjadi disekolah maupun masalah yang terjadi dalam kehidupan sehari-hari. Kemampuan dalam penyelesaian masalah sangat diperlukan dalam kehidupan sehari-hari. Kemampuan pemecahan masalah matematika merupakan suatu keterampilan peserta didik agar mampu menggunakan kegiatan pada pembelajaran dalam menemukan pemecahan masalah matematika. Sependapat dengan Effendi (2012) kemampuan pemecahan masalah harus dimiliki peserta didik untuk melatih agar terbiasa menghadapi berbagai permasalahan, baik masalah dalam matematika, masalah dalam bidang studi lain ataupun masalah dalam kehidupan sehari-hari yang semakin kompleks. Oleh karena itu, kemampuan peserta didik untuk memecahkan masalah matematika perlu terus dilatih sehingga ia dapat memecahkan masalah yang ia hadapi.

Dalam memecahkan masalah terdapat empat indikator yang harus dipenuhi menurut Polya (Hendriana, 2017). Indikator-indikator tersebut adalah: a) memahami masalah, yang meliputi: mengidentifikasi unsur yang diketahui, unsur yang ditanyakan, memeriksa kecukupan unsur untuk penyelesaian masalah, b) mengaitkan unsur yang diketahui dan ditanyakan dan merumuskannya dalam bentuk model maematika masalah, c) memilih strategi penyelesaian, mengelaborasi dan melak- sanakan perhitungan atau menyelesaikan model matematika, d) menginterprestasi hasil terhadap masalah semula dan memerika kembali kebenaran solusi.

Sudah jelas bahwa kemampuan pemecahan masalah matematika merupakan salah satu kemampuan yang harus dimiliki peserta didik. Semakin tinggi jenjang pendidikan peserta didik tersebut, seharusnya semakin baik pula kemampuan pemecahan masalah. Namun pada kenyataannya proses pemecahan masalah masih dianggap sulit bagi kebanyakan peserta didik. Berdasarkan pengamalan peneliti di SMP Negeri 10 Bekasi dan SMP Negeri 26 Bekasi, masih banyak peserta didik yang mengeluh saat diberikan tugas masalah matematis, mereka lebih memilih untuk mengerjakan soal yang langsung dapat diselesaikan menggunakan rumus-rumus yang sudah ada tanpa melewati strategi terlebih dahulu untuk menemukan solusinya. Kesulitan ini dapat disebabkan oleh model pembelajaran yang digunakan guru saat pembelajaran kurang melibatkan peserta didik secara aktif dalam kegiatan pembelajaran. Guru hendaknya menerapkan model pembelajaran yang dapat memberikan kesempatan lebih kepada setiap peserta didik untuk mempelajari materi dan memecahkan masalah-masalah matematika terkait materi yang dipelajari dengan begitu peserta didik akan terbiasa untuk menyelesaikan suatu permasalahan matematika.

Saat ini kebanyakan guru-guru di Indonesia hanya melakukan pembelajaran satu arah. Guru di Indonesia masih menggunakan model pembelajaran tradisional untuk mengajar di kelas dan 
minimnya kreativitas guru dalam mengembangkan model pembelajaran yang sudah ada menjadikan para guru Indonesia menjadi konsumen bukan produsen bagi model pembelajaran di dunia pendidikan. Tidak banyak guruguru di Indonesia yang menggunakan model pembelajaran kooperatif, guruguru di Indonesia hampir sebagian besar hanya menggunakan model pembelajaran konvensional yang dianggap lebih mudah dan simpel untuk digunakan atau diterapkan dalam proses pembelajaran. Menurut Hayat \& Anggraeni (2011) peserta didik kurang didorong untuk mengembangkan kemampuan berpikirnya, sementara guru-guru masih menerapkan metode mengajar secara tradisional, yang berorientasi pada pengukuran kognitif peserta didik saja. Salah satu penyebab proses belajar yang membuat peserta didik bosan adalah guru masih dominan menggunakan pendekatan konvensional atau metode ceramah dan tanya jawab.

Berdasarkan hal tersebut, diperlukan model pembelajaran yang tepat untuk meningkatkan kemampuan pemecahan masalah matematika peserta didik. Saat ini terdapat berbagai macam model pembelajaran yang dikembangkan terutama di Indonesia yang mengacu pada kurikulum 2013 untuk menonjolkan pendidikan karakter dan berfikir tingkat tinggi peserta didik. Dimana model pembelajaran tersebut mampu melibatkan peserta didik secara aktif dan memahami materi dengan baik guna untuk menunjang kelancaraan proses pembelajaran adalah model pembelajaran kooperatif yang dapat meningkatkan hasil belajar peserta didik salah satunya adalah model pembelajaran Team Assisted Individualization.

Model pembelajaran Team Assisted Individualization digagas pertama kali oleh Slavin, model ini dirancang menjadi sebuah bentuk pembelajaran kelompok dengan cara meminta peserta didik bekerja dalam kelompok-kelompok belajar dan bertanggung jawab dalam pengaturan dan pengecekan secara rutin, saling membantu memecahkan masalah dan saling mendorong untuk berprestasi. Slavin (Sanatun \& Sulisworo, 2016) menyatakan bahwa "Team Assisted Individualization (TAI) was created to take advantage of the considerable socialization potential of cooperative learning. Previous studies of group-paced cooperative learning methods have consistenly found positive effects of these methods on such ourcomes as race relations and attitudes toword mainstreamed academically handicapped students". Metode pembelajaran Team Assisted Individualization (TAI) merupakan kombinasi antara pembelajaran kooperatif dengan pengajaran individual (Rudi, 2017; Megawati \& Sari, 2012; Karim \& Anshariyah, 2016; Rohendi, Sutarno, \& Waryuman, 2010; Nurrizki, Widyatiningtyas, \& Retnaningrum, 2016; Sari, Mulyani, \& Mulyani, 2014; Ramlan, 2013) Beberapa hasil penelitian mengenai model ini yaitu bahwa model pembelajaran team assisted individualization dapat meningkatkan hasil belajar, meningkatkan pemahaman peserta didik, membuat peserta didik lebih aktif dan kreatif dan berdampak baik dengan prestasi belajar peserta didik (Ramlan, 
2013; Siswato, 2013; Nurrizki et al., 2016). Proses pembelajaran membutuhkan persiapan yang baik dan matang untuk menjalan model pembelajaran ini. Model pembelajaran ini dapat membuat peserta didik mengembangkan kemampuan individu sekaligus dapat membuat peserta didik bersosialisasi dengan teman-temannya. Namun, setiap model pembelajaran kooperatif memiliki kekurangan atau kelemahannya, sama halnya dengan model pembelajaran team assisted individualization. Model pembelajaran Team Assisted Individualization ini memiliki kekurangan salah satunya yaitu jika dalam suatu kelas terlalu banyak peserta didik, guru akan kesulitan menjalankan model pembelajaran ini karena akan ada peserta didik yang tidak aktif.

Model pembelajaran Team Assisted Individualization (TAI) selain dapat membuat peserta didik aktif dan meningkatkan hasil belajar peserta didik, tetapi model pembelajaran ini juga memiliki kekurangan tersendiri. Model pembelajaran ini terbagi kedalam beberapa tahap, karena tahapan yang panjang membuat guru harus mempersiapkan dengan matang sebelum menggunakan model pembelajaran team assisted individualization ini. Kekurangan model pembelajaran ini terjadi dikarenakan tidak adanya pemberian tugas secara rutin. Pemberian tugas secara rutin sangat penting digunakan untuk menghindari peserta didik dari sifat malas. Maksud dari pemberian tugas secara rutin untuk meningkatkan hasil belajar peserta didik. Maka dari itu peneliti ingin memodifikasi model pembelajaran Team Assisted Individuali- zation dengan strategi pembelajaran tugas dan paksa. Tujuan memodifikasi model pembelajaran Team Assisted Individualization dengan strategi pembelajaran tugas dan paksa yaitu untuk mengatasi kekurangan dari model pembelajaran Team Assisted Individualization yang sebelumnya sudah diuraikan. Strategi pembelajaran tugas dan paksa dipilih untuk menghilangkan sifat malas belajar yang selama ini sudah menjadi kebiasaan peserta didik di Indonesia. Peserta didik di Indonesia tidak akan belajar jika tidak diberikan tugas dan sedikit paksaan, hal ini yang dilakukan agar peserta didik mau mengerjakan tugas yang diberikan. Sama halnya dengan yang diungkapkan oleh Leonard (2018), because of the character, some of Indonesian whoever must be given the task to work and forced to do something and even punishment if don't, so the writer tries to develop the instructional strategy based on the background.

Strategi pembelajaran tugas dan paksa merupakan salah satu strategi pembelajaran yang menekankan pada pemberian tugas dengan sedikit paksaan. Pemberian tugas dan paksaan diperlukan karena melihat sekarang ini banyak peserta didik terutama di Indonesia yang malas mengerjakan tugasnya jika tidak dipaksa. Peserta didik hanya mau mengerjakan tugasnya jika guru memberikan hukuman kepada peserta didik yang tidak mengerjakan tugas. Pemberian tugas dalam proses pembelajaran dapat mengukur seberapa jauh tingkat pemahaman peserta didik. Menurut Lee, Lee, \& Park (2016), tasks can be designed in different forms 
according to the objective and orientation, and every single task form provides a different learning opportunity for students. Maka dari itu perlu adanya tugas saat proses pembelajaran. Namun, paksaan juga harus ada dalam proses pembelajaran, paksaan yang dilakukan untuk membuat peserta didik disiplin dalam mengerjakan tugas dan tidak menunda-nunda tugas yang diberkan oleh guru. Disiplin adalah salah satu faktor dari keberhasilan peserta didik, sama halnya dengan yang dikemukakan oleh Jamhal (2015) kedisiplinan merupakan faktor utama yang menunjang keberhasilan dalam memajukan pendidikan. Apabila di suatu lingkungan sekolah memiliki tingkat kedisiplinan yang rendah. Maka tidak menutup kemungkinan sekolah tersebut melahirkan generasi yang kurang bermutu, dengan kata lain tinggi rendahnya penegakkan kedisiplinan sekolah menentukan tinggi rendahnya mutu sumber daya manusia yang diciptakannya. Sedangkan menurut Sadik (2017), discipline problems can be observed at any level of education and cause stress for the educator. Jadi kedisiplinan adalah faktor penting dalam menciptakan generasi penerus bangsa yang berkualitas, dengan adanya peserta didik yang tidak disiplin akan membuat proses pembelajaran menjadi terhambat. Dari uraian terseut, maka peneliti mencoba memodifikasi model pembelajaran Team Assisted Individualization dengan strategi pembelajaran tugas dan paksa agar dapat meningkatkan kualitas pembelajaran, meningkatkan pemahaman peserta didik dalam menyelesaikan pemecahan masalah, serta meningkatkan hasil belajar. Masih banyaknya masalah dalam proses pembelajaran seperti masih rendahnya pemahaman peserta didik terhadap materi yang diberikan guru serta cara guru dalam mengajar yang belum efektif membuat hasil belajar peserta didik belum maksimal. Adanya modifikasi ini diharapkan bisa menanggulangi permasalahan-permasalahan tersebut.

\section{METODE PENELITIAN}

Penelitian ini menggunakan metode quasi eksperimen. Sampel penelitiannya yaitu peserta didik kelas VIII di SMP Negeri 10 Bekasi dan SMP Negeri 26 Bekasi. Tahun ajaran 2018/2019 yang berjumlah 60 peserta didik yang terdiri dari 30 peserta didik kelas eksperimen dan 30 peserta didik kelas kontrol. Desain penelitian yang dilakukan dalam penelitian ini adalah posttest-only. Dalam penelitian ini terdapat kelas eksperimen dan kelas kontrol. Kelas eksperimen adalah kelas yang dalam kegiatan pembelajarannya menggunakan model pembelajaran Team Assisted Individualization dengan strategi pembelajaran tugas dan paksa, sedangkan kelas kontrol kegiatan pembelajarannya menggunakan model pembelajaran langsung.

Teknik pengumpulan data yang dilakukan dengan cara memberikan soal esai kepada peserta didik sebanyak 10 soal. Dari 10 soal instrument yang valid 9 butir soal. Berdasarkan hasil perhitungan tersebut terdapat 6 soal dengan tingkat kesukaran mudah dan terdapat 3 soal dengan tingkat kesukaran sedang dan terdapat 1 soal dengan tingkat kesukaran tinggi. 
Tabel 1. Desain Penelitian

\begin{tabular}{ccc}
\hline Kelompok & Perlakuan & Post Test \\
\hline ( R ) E & $\mathrm{X}_{\mathrm{E}}$ & $\mathrm{Y}_{\mathrm{E}}$ \\
$(\mathrm{R}) \mathrm{K}$ & $\mathrm{X}_{\mathrm{K}}$ & $\mathrm{Y}_{\mathrm{K}}$ \\
\hline
\end{tabular}

E : Kelompok kelas eksperimen

$\mathrm{K} \quad$ : Kelompok kelas kontrol

$\mathrm{X}_{\mathrm{E}}$ : Perlakuan dengan menggunakan model pembelajaran Team Assisted Individualization dengan Strategi Pembelajaran Tugas dan Paksa

$\mathrm{X}_{\mathrm{K}}$ : Perlakuan dengan menggunakan model pembelajaran langsung

$\mathrm{Y}_{\mathrm{E}}$ : Tes pada kelas yang diajarkan dengan model pembelajaran Team Assisted Individualization dengan Strategi Pembelajaran Tugas dan Paksa

$\mathrm{Y}_{\mathrm{K}}$ : Tes pada kelas yang diajarkan menggunakan model pembelajaran langsung

Pada metode pembelajaran modifi-

kasi ada beberapa tahapan yang akan digunakan. Tahapan-tahapan tersebut di antaranya adalah sebagai berikut. 1) Tahap persiapan tentang awal mulai pembela-jaran, guru memberikan motivasi kepada peserta didik bahwa keberhasilan dalam belajar ditentukan oleh kemampuan individu dan juga kejujuran. Ditahap ini guru memberitahu kepada peserta didik bahwa dalam proses pembelajaran akan ada beberapa tugas yang harus dikerjakan seperti, tugas jangka panjang, tugas rutin, dan tugas spontan yang harus dikerjakan peserta didik dengan waktu pengumpulan tugas yang telah disepakati. Adapun rencana penugasan jangka panjang seperti membuat rangkuman materi pembelajaran dari awal hingga akhir. Rencana tugas rutin seperti mengerjakan soal tentang materi yang diajarkan seperti mengerjakan soal di LKS. Rencana tugas spontan seperti tugas yang diberikan secara mendadak.
Misalnya jika ada peserta didik yang belum memahami materi pembelajaran mereka akan bertanya kepada gurunya maka pertanya peserta didik tersebut dijadikan tugas spontan yang berlaku untuk semua peserta didik. 2) Adanya kontrak belajar yang dilakukan antara guru dan peserta didik, seperti ada kesepakatan antara peserta didik dan guru mengenai hukuman yang akan diberikan kepada peserta didik jika peserta didik tidak mengerjakan tugasnya tepat waktu. Hukuman yang akan diberikan seperti pengurangan skor penilaian dan tugas tambahan. 3) Tahap akhir yaitu pemberian tugas jangka panjang atau tugas akhir dari proses pembelajaran sekaligus pengumpulan tugas tersebut.

Langkah-langkah model pembelajaran Team Assisted Individualization dengan strategi pembelajaran tugas dan paksa adalah sebagai berikut.

1. Guru menyampaikan tujuan pembelajaran, memberikan motivasi kepada peserta didik bahwa keberhasilan didalam pembelajaran ditentukan oleh kemampuan individu serta kejujuran, dan menyampaikan gambaran manfaat mempelajari materi dalam kehidupan sehari-hari, setelah itu guru memberitahu bahwa akan adanya tugas jangka panjang, tugas rutin mingguan dan tugas spontan. Serta meyakinkan peserta didik banwa tugas yang tidak dikerjakan secara maksimal maka akan mendapatkan hukuman.

2. Guru memberikan tugas jangka panjang yang akan dikumpulkan di akhir pertemuan serta tugas rutin 
mingguan yang harus dikumpulkan dipertemuan selanjutnya.

3. Guru menyampaikan materi pembelajaran, serta memberikan contoh soal.

4. Guru memberikan soal awal untuk mengetahui kemampuan awal peserta didik.

5. Guru membagi siswa menjadi 4-5 siswa dengan kemampuan berbeda. Kemampuan tersebut dilihat dari hasil ulangan harian pada materi sebelumnya.

6. Kemudian, guru membagikan lembar kerja siswa kepada masingmasing siswa. Setiap siswa mengerjakan soal tersebut secara individu terlebih dahulu, kemudian setiap kelompok berdiskusi membandingkan jawabannya.

7. Setelah itu, perwakilan salah satu kelompok mempresentasikan hasil diskusinya dan kelompok lain menanggapi.

8. Guru memberikan soal post tes latihan lagi kepada siswa yang dikerjakan secara individu untuk membuktikan kemampuan mereka yang sebenarnya.

9. Jika ada murid yang bertanya berikan tugas spontan dimana semua peserta didik harus ikut mencari tahu jawabannya.

10. Akhir pembelajaran guru dan siswa menarik kesimpulan materi yang telah dipelajari, memberikan penghargaan bagi yang dianggap sebagai tim super, dan memberikan hukuman kepada peserta didik yang tidak tertib dan tidak disiplin dengan mendapat nilai kurang dari rata dengan memberikan pekerjaan rumah.

11. Di pertemuan terakhir (akhir semester) tugas jangka panjang harus dikumpulkan.

\section{HASIL DAN PEMBAHASAN Deskripsi Data}

Berdasarkan data kemampuan pemecahan masalah matematika pada materi pola bilangan yang diajar dengan model pembelajaran Team Assisted Individualization diperoleh rentang nilai dari 56 sampai 91 dengan nilai rata-rata 73,90 modus 74,52 median 76,50; varians sebesar 113,42 dan simpangan baku sebesar 10,56.

Berdasarkan data kemampuan pemecahan masalah matematika pada materi pola bilangan yang diajar dengan model pembelajaran Team Assisted Individualization diperoleh rentang nilai dari 52 sampai 81 dengan nilai rata-rata 66,83 modus 66,50 median 74,50; varians sebesar 78,76 dan simpangan baku sebesar 8,87 .

\section{Uji Persyaratan Analisis Data Normalitas}

Dalam penelitian ini, uji normalitas data dianalisis dan diuji dengan teknik uji Chi-kuadrat. Hipotesis statistik statistik yang diuji adalah:

$\mathrm{H}_{0}$ : data berasal dari populasi berdistribusi normal,

$\mathrm{H}_{1}$ : data berasal dari populasi berdistribusi normal.

Kriteria pengujian yaitu: terima $\mathrm{H} 0$ jika $\mathrm{L}_{\mathrm{o}}<\mathrm{L}_{\text {tabel, }}$ dan tolak $\mathrm{H}_{0}$ jika $\mathrm{L}_{0}>\mathrm{L}_{\text {tabel. }}$. 


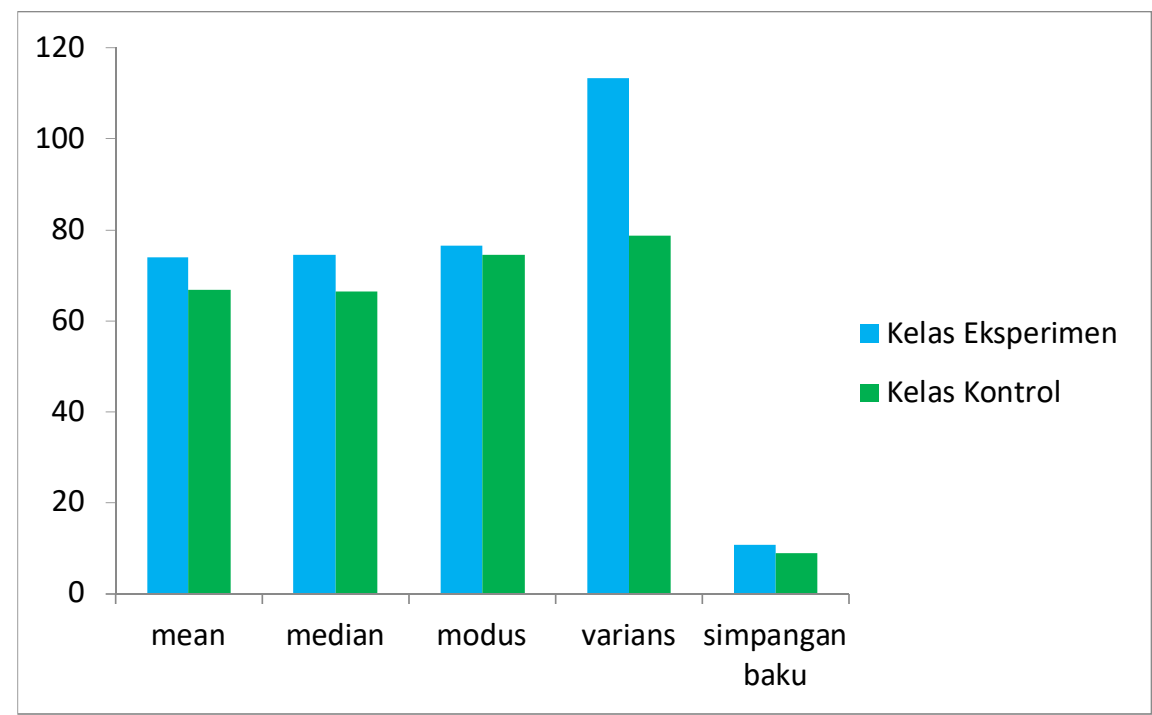

Gambar 1. Diagram Perbedaan Kelas Eksperimen dan Kelas Kontrol

Dari tabel uji normalitas tes kemampuan pemecahan masalah matematika pada materi pola bilangan kelompok eksperimen didapat $L_{o}=5,99$ dan pada kelompok kontrol didapat $L_{o}=$ 7,50 , sedangkan $L_{t}$ untuk $\mathrm{n}=30$ pada taraf signifikan 0,05 sebesar 11,07. karena nilai $L_{t}$ pada dua kelompok penelitian tersebut diperoleh $L_{o}<L_{t}$. Berarti kedua kelompok penelitian tersebut berasal dari populasi berdistribusi normal.

\section{Uji Homogenitas Data}

Dari hasil perhitungan uji homogenitas, didapat nilai $F_{\text {hitung }}=1,44$ dan didapat $F_{\text {tabel }}=1,85$. karena nilai $F_{\text {hitung }}<F_{\text {tabel }}$ atau $1,44<1,85$, sehingga dapat disimpulkan bahwa kedua data memiliki varians yang homogen.

\section{Pengujian Hipotesis}

Setelah dilakukan uji persyaratan analisis data, diperoleh bahwa kedua kelompok berdistribusi normal dan homogen. Selanjutnya, akan dilakukan uji hipotesis penelitian menggunakan uji-t dengan hipotesis sebagai berikut.

$$
\begin{aligned}
& H_{0}: \mu_{A} \leq \mu_{B} \\
& H_{1}: \mu_{A}>\mu_{B}
\end{aligned}
$$

Setelah melakukan perhitungan menggunakan uji $\mathrm{t}$ maka diperoleh $t_{\text {hitung }}=2,79$ dan dengan menggunakan tabel $\mathrm{t}$ dengan derajat kebebasan $d k=n_{A}+n_{B}-2$ dan taraf signifikansi $\alpha=0,05$, diperoleh $t_{\text {tabel }}=1,67$. Hasil perhitungan menunjukan bahwa $t_{\text {hitung }}>t_{\text {tabel }}$ maka $\mathrm{H}_{1}$ diterima dan $\mathrm{H}_{0}$ ditolak. Dapat disimpulkan bahwa rata-rata kemampuan pemecahan masalah matematika peserta didik pada peserta didik kelas eksperimen yang diajarkan dengan menggunakan model pembelajaran Team Assisted Individualization dengan strategi pembelajaran tugas dan paksa lebih tinggi dari pada peserta didik kelas kontrol yang diajar dengan model pembelajaran langsung. Hal ini berarti bahwa model pembelajaran Team Assisted Individualization dengan strategi pembelajaran tugas dan paksa berpengaruh terhadap kemampuan 
pemecahan masalah matematika peserta didik.

Berdasarkan data penelitian di atas dapat disimpulkan bahwa kelas eksperimen dengan model pembelajaran Team Assisted Individualization dengan strategi pembelajaran tugas dan paksa menghasilkan data mean, median, modus, varians, dan simpangan baku yang lebih tinggi dari kelas kontrol dengan model pembelajaran langsung.

\section{Pembahasan}

Dalam pembelajaran matematika peran model, metode dan strategi pembelajaran sangat besar terhadap kemampuan pemecahan masalah matematika peserta didik dalam menerima materi-materi baru. Untuk itu, penulis tidak menekankan bahwa model atau metode pembelajaran terbaik adalah model pembelajaran Team Assisted Individualization dengan strategi pembelajaran tugas dan paksa, akan tetapi model pembelajaran Team Assisted Individualization dengan strategi pembelajaran tugas dan paksa yang dikembangkan searah dengan pelaksanaan model pembelajaran kreatif dapat membantu peserta didik dalam menerima materimateri baru serta membuat peserta didik lebih disiplin.

Model Pembelajaran Team Assisted Individualization (TAI) membantu peserta didik yang kesulitan dalam belajar secara individu. Pengelompokkan yang dilakukan secara heterogen memudahkan peserta didik untuk bekerja sama dalam mendiskusikan halhal yang belum dimengerti dengan teman sekelompoknya (teams). Pemberian pre-test dapat mengetahui kelemahan dari setiap peserta didik sehingga pendidik dapat mencari solusinya (Placment Test). Individu menyelesaikan tugas dalam suatu kelompok dapat dikatakan berhasil ditentukan oleh keberhasilan kelompoknya (Student Creative). Selain ditentukan dari keberhasilan kelompoknya, individu yang berhasil menyelesaikan tugasnya juga menerima bantuan secara individual dari pendidik agar kesulitan yang dihadapinya dapat terselesaikan (Team Study). Pemberian skor terhadap hasil kerja kelompok dan kriteria penghargaan terhadap kelompok yang berhasil dan kelompok yang kurang berhasil sehingga dapat memotivasi peserta didik dalam menyelesaikan tugas-tugasnya (Team Score and Team Recorginition). Pemberian materi secara singkat oleh pendidik sebelum pemberian tugas kelompok dapat mempermudah peserta didik menyelesaikan tugas-tugasnya (Teaching Group). Dalam proses mengerjakan tugas kelompok banyak ditemukan oleh peserta didik berupa fakta-fakta maka dibuatlah suatu tes-tes kecil agar dapat memudahkan peserta didik mengingatnya (Fact Test). Pemberian materi kembali diakhir pembelajaran dapat mengevaluasi hasil belajar yang didapatkan oleh peserta didik dengan strategi pemecahan masalah (Whole-Class Units) (Nurrizki, Widyatiningtyas, \& Retnaningrum, 2016).

Penelitian ini memberikan hasil adanya perbedaan kemampuan pemecahan masalah matematika peserta didik yang diajar menggunakan model pembelajaran Team Assisted Individualization dengan strategi pembelajaran tugas dan 


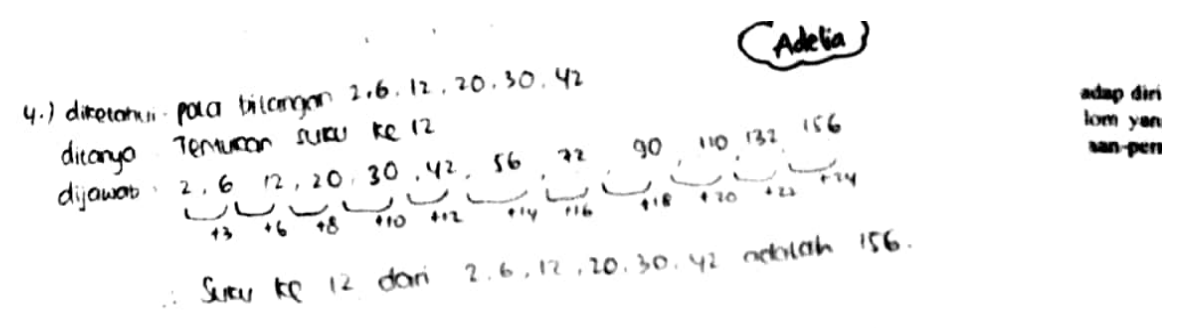

(Anis)

4.). Diketahui = Pola bilangan $2,6,12,20,30,42 \ldots$ di tanya. : Suka ke le.

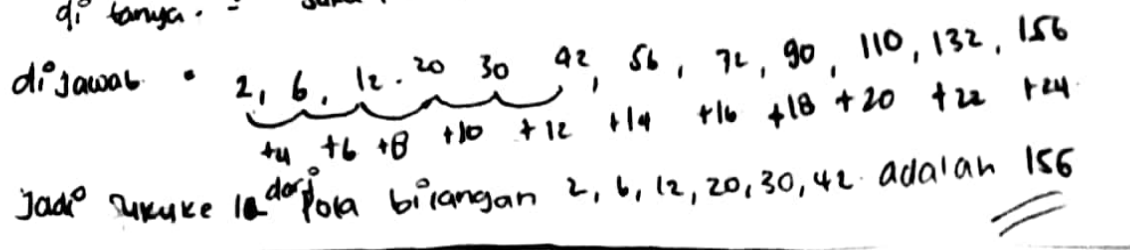

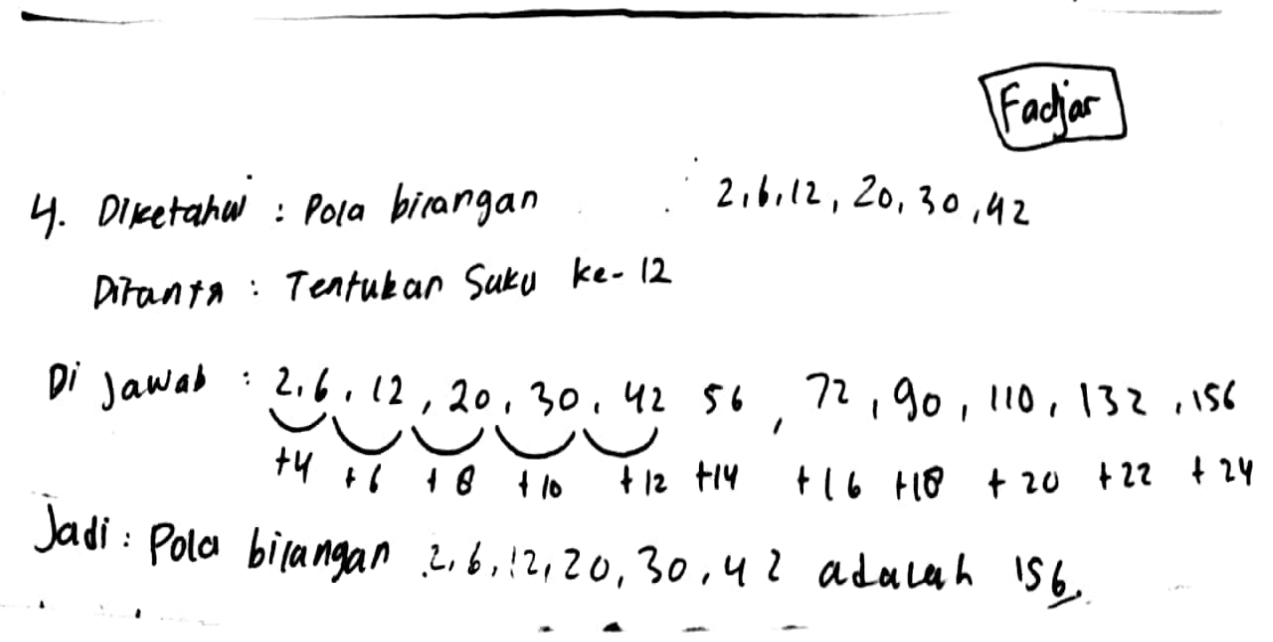

Gambar 2. Jawaban Siswa Kelas Eksperimen

paksa dan model pembelajaran langsung. Gambar 2 dan 3 menunjukkan perbedaan jawaban dari soal yang sama yang dikerjakan peserta didik di kelas eksperimen dan di kelas kontrol.

Rata-rata peserta didik yang diajar menggunakan model pembejaran Team Assisted Individualization dengan strategi pembelajaran tugas dan paksa akan menjawab soal yang diberikan dengan teliti dan terperinci. Peserta didik yang berada di kelas eksperimen menjawab soal yang diberikan dengan detail dan tidak hanya terpaku kepada rumus. Peserta didik yang berada di kelas eksperimen menjawab soal dengan aturan yang benar sesuai dengan yang diajarkan oleh sebelumnya, mereka menjawab soal dengan tahapan yang telah dipelajari sebelumnya seperti mengidentifikasi masalah, membuat rencana pemecahan masalah, menyele- 


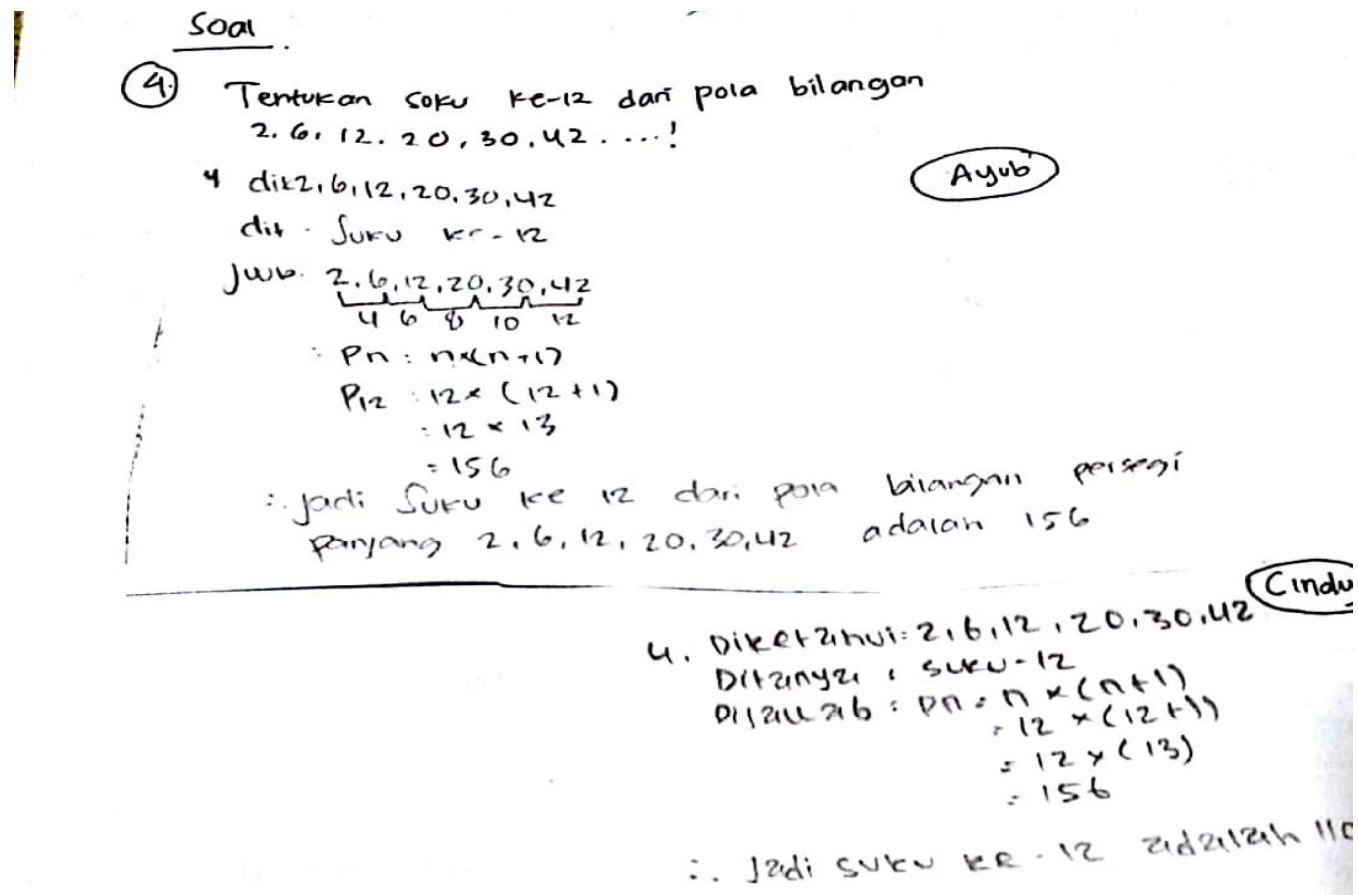

4. Diketahui $=$ pala bilangan $2,6,12,20,30,42$

$$
\begin{aligned}
& \text { Ditanya }=\text { Suku ke }-12 ? \\
& \text { Dijawab }-p_{n}=n(n+1) \\
& P_{12}=12(12+1) \\
&=12(13) \\
&=156
\end{aligned}
$$

Jadi, suku ke - 12 pada pola bilangan $2,6,12,20,30,42$ adalah $=156$

Gambar 3. Jawaban Siswa Kelas Kontrol

saikan masalah sesuai rencana pemecahan masalah dan yang terakhir menarik kesimpulan dari hasil pemecahan masalah. Sama halnya dengan yang dikatakan oleh Karim \& Anshariyah (2016) bahwa model pembelajaran kooperatif tipe Team Assisted Individualization (TAI) dapat membantu peserta didik untuk melatih kemampuan pemecahan masalah matematika, hal ini dikarenakan pada sintak belajar kelompok peserta didik dilatih untuk memecahkan masalah-masalah terkait materi individu. Hal ini memungkinkan peserta didik untuk memahami masalah kemudian mencari solusi dengan strategi penyelesaian mereka masing-masing. Sedangkan peserta didik berada di kelas kontrol menjawab soal dengan kurang detail serta hanya lebih terpaku kepada rumusrumus yang ada tanpa mau bersusah payah untuk memecahkan masalah terlebih dahulu, mereka kurang 
memperhatikan proses menjawab yang benar sesuai dengan yang telah diajarkan sebelumnya.

Strategi pembelajaran tugas dan paksa membuat peserta didik jauh lebih disiplin dan aktif, sama halnya dengan yang dikatakan oleh Widodo, Murtini, \& Susilowati (2016) bahwa metode pemberian tugas dan resitasi dilakukan dengan memaksa siswa belajar agar merangsang untuk siswa lebih aktif dalam belajar serta mengembangkan kreativitas secara invidual maupun kelompok, dapat menimbulkan kemandirian siswa di luar pengawasan guru sehingga terbinanya tanggung jawab dan disiplin. Dengan memupuk kedisiplinan belajar peserta didik maka prestasi belajarnya juga akan meningkat, sama halnya dengan yang dikatakan Kusuma \& Subkhan, (2015) bahwa selain motivasi belajar, faktor lain mempengaruhi tinggi rendahnya prestasi belajar adalah disiplin belajar siswa dalam pembelajaran. Di dalam strategi pembelajaran tugas dan paksa juga ditekankan kepada pemberian motivasi untuk membangkitkan semangat belajar peserta didik serta meningkatkan prestasi belajar peserta didik. Hal ini sesuai dengan Lestari (2010) bahwa Selain strategi pembelajaran yang digunakan dalam proses belajar mengajar, terdapat faktor lain yang mempengaruhi prestasi belajar matematika peserta didik. Salah satu faktor lain tersebut adalah motivasi belajar peserta didik. Motivasi merupakan faktor internal yang dimiliki oleh setiap peserta didik dan sangat mempengaruhi dalam mencapai hasil belajar. Hal ini diperkuat oleh Kusuma \& Subkhan (2015) bahwa motivasi sangat penting dalam kegiatan belajar mengajar, sebab adanya motivasi mendorong semangat belajar dan sebaliknya kurang adanya motivasi akan melemahkan semangat belajar. Seorang siswa yang belajar tanpa motivasi atau kurang motivasi, tidak akan berhasil dengan maksimal. Dengan pemberian motivasi serta tugas akan meningkatkan kedisiplinan peserta didik yang akan berdampak baik terhadap prestasinya.

Berdasarkan hasil penelitian sebelumnya yang dilakukan oleh Karim dan Anshariyah (2016), disimpulkan bahwa sebanyak 34 peserta didik atau 80,20\% memiliki kemampuan pemecahan masalah dengan kualifikasi yang baik dengan rata-rata kemampuan pemecahan masalah peserta didik 72,75 dengan kualifikasi yang baik. Model pembelajaran tipe Team Assisted Individualization dapat membantu peserta didik untuk melatih kemampuan pemecahan masalah matematika peserta didik. Hal ini dikarenakan, pada sintak belajar kelompok peserta didik dilatih untuk menyelesaikan masalah-masalah terkait materi secara individu (Karim \& Anshariyah, 2016).

Secara garis besar dalam penelitian ini, bahwa rata-rata kemampuan pemecahan masalah matematika peserta didik yang diajar menggunakan model pembelajaran Team Assisted Individualization dengan strategi pembelajaran tugas dan paksa lebih baik dari rata-rata kemampuan pemecahan masalah matematika peserta didik diajar menggunakan model pembelajaran langsung. Hal ini menandakan bahwa model pembelajaran Team Assisted Individualization dengan strategi pembelajaran 
tugas dan paksa yang diberikan kepada kelas eksperimen dapat mendorong minat belajar peserta didik dalam mata pelajaran matematika. Model pembelajaran Team Assisted Individualization dengan strategi pembelajaran tugas dan paksa menantang peserta didik untuk bekerjasama dengan kelompoknya, agar mendapatkan nilai yang tertinggi serta peserta didik dilatih untuk disiplin dengan tugas-tugas yang diberikan. Dengan kata lain, model pembelajaran Team Assisted Individualization dengan strategi pembelajaran tugas dan paksa dapat memberikan dampak yang positif terhadap peserta didik dan mengakibatkan perbedaan kemampuan pemecahan masalah matematika peserta didik dibandingkan metode pembelajaran lainnya.

Sebaliknya, pada kelas kontrol (model pembelajaran langsung), ratarata kemampuan pemecahan masalah matematika peserta didik cenderung lebih rendah. Hal ini dikarenakan kurang aktifnya peserta didik dalam pembelajaran, karena model pembelajaran yang kurang efisien dan kurang kreatif, sehingga membuat peserta didik menjadi tidak semangat untuk belajar. Dari situlah terlihat bahwa dalam satu kelas pasti hanya beberapa peserta didik saja yang memperhatikan mata pelajaran matematika yang diajarkan.

Dari uraian di atas, dapat disimpulkan bahwa terdapat pengaruh antara model pembelajaran Team Assisted Individualization dengan strategi pembelajaran tugas dan paksa terhadap kemampuan pemecahan masalah matematika peserta didik. Hal ini dapat terjadi karena dalam model pembelajaran Team
Assisted Individualization dengan strategi pembelajaran tugas dan paksa setiap peserta didik sangat bersemangat dalam belajar, karena model pembelajaran yang mudah dimengerti, efisien dan kreatif. Dengan demikian, semua peserta didik terpacu dalam kemampuan pemecahan masalah matematika dan menjadikan peserta didik dapat mudah mendapatkan hasil yang terbaik.

\section{PENUTUP}

Model pembelajaran pembelajaran Team Assisted Individualization dengan strategi tugas dan paksa terbukti dapat meningkatkan kemampuan pemecahan masalah matematika peserta didik. Peserta didik terbiasa dilatih dengan tugas-tugas yang diberikan seperti tugas jangka panjang, tugas minggguan, dan tugas dadakan. Mereka dilatih untuk memecahkan masalah-masalah yang dihadapi setiap pelajaran matematika. Model pembelajaran Team Assisted Individualization dengan strategi tugas dan paksa membuat anak lebih disiplin dalam proses pembelajaran dan berdampak baik bagi hasil belajar dan juga prestasi belajar disekolah. Namun, model pembelajaran Team Assisted Individualization dengan strategi tugas dan paksa ini masih sebatas teori saja dan masih perlu dikembangkan lebih lanjut untuk mengukur seberapa efektif model pembelajaran Team Assisted Individualization dengan strategi tugas dan paksa ini dalam proses pembelajaran di sekolah.

Berdasarkan hasil penelitian maka peneliti mengajukan beberapa saran sebagai berikut. 1) Untuk menerapkan model pembelajaran Team Assisted 
Individualization dengan strategi tugas dan paksa ini, guru harus mempersiapkannya dengan matang. Guru hendaknya memahami dan menguasai terlebih dahulu konsep dari model pembelajaran team assisted individualization dengan strategi tugas dan paksa. 2) Karena ini masih sebuah teori maka perlu dilakukan penelitian lebih lanjut, untuk melihat keefektifan model pembelajaran Team Assisted Individualization dengan strategi pembelajaran tugas dan paksa dalam pembelajaran sehingga benarbenar bisa diterapkan diberbagai sekolah.

\section{DAFTAR PUSTAKA}

Afandi, R., \& Sidoarjo, U. M. (2011). Integrasi pendidikan karakter dalam pembelajaran ips di sekolah dasar. Pedagogia , 1(1), 85-98.

Ariananda, E. S., Hasan, S., \& Rakhman, M. (2014). Pengaruh kedisiplinan siswa di sekolah terhadap prestasi belajar siswa teknik pendingin. Journal of Mechanical Engineering Education, 1(2), 233238.

Dacholfany, M. I. (2016). Peranan pengambilan keputusan dalam rangka menciptakan inovasi di bidang pendidikan. Dewantara, 1(1), 16-28.

Effendi, L. A. (2012). Pembelajaran matematika dengan metode penemuan terbimbing untuk meningkatkan kemampuan representasi dan pemecahan masalah matematis siswa smp. Jurnal Penelitian Pendidikan, 13(2), 1-10. Retrieved from http://jurnal.upi.edu/file/Leo_Adh ar.pdf.

Eka S. Ariananda, D. (2014). Pengaruh
Kedisiplinan Siswa Di Sekolah Terhadap Prestasi Belajar Siswa Teknik Pendingin. Journal of Mechanical Engineering Education, 1(2), 233-238.

Gungor, S. N., \& Ozkan, M. (2017). Children and Discipline: Investigating Secondary School Students' Perception of Discipline through Metaphors. European Journal of Educational Research, 6(4), 31-45. https://doi.org/10.12973/eujer.6.4.495

Hayat, M. S., \& Anggraeni, S. (2011). Pembelajaran berbasis praktikum pada konsep invertebrata untuk pengembangan sikap ilmiah siswa. Jurnal Bioma, 1(2), 141-152.

Hermawan, H., \& Paloloang, B. (2012). Penerapan model pembelajaran kooperatif tipe team assisted individualization ( TAI ) untuk meningkatkan hasil belajar siswa kelas V SDN 4 Bajugan pada operasi hitung campuran. Jurnal Kreatif Tadulako, 4(9), 44-60.

Jamhal, F. (2015). Implementasi metode pembelajaran discovery dalam meningkatkan kedisiplinan dan konsentrasi belajar peserta didik kelas XI b MA Madani Alauddin Paopao. Jurnal Pendidikan Fisika, 3(2), 137-142.

Karim, \& Anshariyah, A. (2016). Penerapan model pembelajaran kooperatif tipe team assisted individualization (TAI) untuk melatih kemampuan kemecahan masalah katematis siswa SMA. EDU-MAT Jurnal Pendidikan Matematika, 4(1), 58-67.

Kusuma, Z. L., \& Subkhan. (2015). Pengaruh motivasi belajar dan kedisiplinan belajar terhadap prestasi belajar mata pelajaran 
akuntansi siswa kelas XI IPS SMA Negeri 3 Pati tahun pelajaran 2013/2014. Economic Education Analysis Journal, 4(1), 164-171.

Lee, K., Lee, E., \& Park, M. (2016). Task Modification and Knowledge Utilization by Korean Prospective Mathematics Teachers. Pedagogical Research, 1(2), 1-13.

Leonard. (2018). Task and forced instructional strategy: instructional strategy based on character and culture of indonesia nation. Formatif:Jurnal Ilmiah Pendidikan MIPA, 8(1), 51-56. https://doi.org/http://dx.doi.org/10 .30998/formatif.v8i1.2408

Martiawan, F. (2015). Paksaan ekonomi dan penyalahgunaan keadaan sebagai bentuk cacat kehendak dalam perkembangan hukum kontrak. Jurnal Yuridika, 30(2), 232-253.

https://doi.org/10.20473/ydk.v30i 2.468 .

Megawati, Y. D. N., \& Sari, A. R. (2012). Model pembelajaran kooperatif tipe team assisted individualization (TAI) dalam meningkatkan keaktifan siswa dan hasil belajar akuntansi siswa kelas XI IPS 1 SMA Negeri 1 Banjarnegara Tahun Ajaran 2011/2012. Jurnal Pendidikan Akuntansi Indonesia, X(1), 162 180. Retrieved from http://journal.uny.ac.id/index.php/ jpakun/article/download/927/738.

Neo, M., Neo, K. T. K., \& Lim, S. T. L. (2013). Designing a web-based multimedia learning environment with Laurillard's conversational framework: An investigation on instructional relationships. Turkish Online Journal of Educational Technology, 12(3), 39-50.
https://doi.org/10.1017/CBO9781 107415324.004 .

Nurrizki, D., Widyatiningtyas, R., \& Retnaningrum, E. (2016). Pengaruh model pembelajaran TAI terhadap peningkatan kemampuan pemecahan masalah matematis siswa SMA. In Prosiding Seminar Nasional Matematika dan Pendidikan Matematika UNY (pp. 291-296).

Putri, R. H. W. (2017). Eksperimen pembelajaran matematika dengan strategi team assisted individualization dan quiz team ditinjau dari kemampuan pemecahan masalah siswa kelas VIII di SMP Muhammadiyah 8 Surakarta. In Prosiding Seminar Nasional Pendidikan Matematika 2017. (pp. 1-11).

Qoyyimah, D. (2014). Peningkatan aktivitas dan hasil belajar pokok bahasan pasar dengan metode resitasi pada siswa kelas viii SMP Negeri 24 Semarang tahun ajaran 2013/2014. Economic Education Analysis Journal, 2(3), 188-199.

Ramlan. (2013). Meningkatkan selfefficacy pada pembelajaran matematika melalui model kooperatif tipe team assisted individualitazion (TAI) pada siswa kelas VIIA SMP Negeri 27 Makassar. Jurnal Matematika Dan Pembelajaran (MAPAN), 1(1), 110.

Robertson, E. P., \& Jung, J. (2006). The asian efl journal quarterly september 2006 special conference proceedings volume: task-based learning in the asian context. Asian EFL Journal, 8(3), 1-298.

Rohendi, D., Sutarno, H., \& Waryuman, D. R. (2010). Team assisted individualization untuk 
meningkatkan hasil belajar siswa pada mata pelajaran teknologi informasi dan komunikasi. Jurnal Pendidikan Teknologi Informasi Dan Komunikasi (PTIK), 3(1), 3337.

Rudi, L. (2017). Application of teaching model of team assisted individualization (TAI) in basic chemistry courses in students of forestry and science of environmental Universtias Halu Oleo. International Journal of Education and Research, 5(11), 69-76. Retrieved from www.ijern.com.

Sadik, F. (2017). Children and discipline: investigating secondary school students' perception of discipline through metaphors. European Journal of Educational Research, 7(1), 31-45. https://doi.org/10.12973/eujer.7.1.31

Sanatun, N. A., \& Sulisworo, D. (2016). Implementasi metode drill and practice secara kelompok untuk peningkatan prestasi belajar. Jurusan Pendidikan Fisika, 3(1), 67-71. Retrieved from http://journal.unnes.ac.id/sju/inde x.php/upej.

Sari, D. K., Mulyani, B., \& Mulyani, S. (2014). Studi komparasi metode pembelajaran kooperatif team assisted individualization ( TAI ) dan cooperative problem solving ( CPS ) terhadap prestasi belajar ditinjau dari kemampuan matematik siswa pada materi kelarutan dan hasil kali kelarutan kelas XI IPA SM. Jurnal Pendidikan Kimia (JPK), 3(1), 5157.

Siswato, Y. (2013). Penerapan model pembelajaran kooperatif tipe team assisted individualization (TAI) untuk meningkatkan hasil belajar akuntansi siswa kelas Xl Ak 1 SMK Abdi Negara Muntilan Tahun Ajaran 2012/2013. Jurnal Pendidikan Teknik Mesin, 1(3), 72-79.

Sutriningsih, N. (2015). Model pembelajaran team assisted individualization berbasis assessment for learning pada persamaan garis lurus ditinjau dari karakteristik. Jurnal E-DuMath, 1(1), 43-52. https://doi.org/23562056.

Widhiantari, R. (2012). Efektivitas metode pemberian tugas (resitasi) berbantuan modul pembelajaran terhadap hasil belajar siswa kompetensi dasar uang dan perbankan SMAN 1 Kota Mungkid Kabupaten Magelang. Economic Education Analysis Journal, 1(1), 1-6.

Widodo, W., Murtini, W., \& Susilowati, T. (2016). Penerapan metode pemberian tugas dan resitasi dalam upaya meningkatkan kemampuan menulis surat siswa kelas $\mathrm{x} d$ administrasi perkantoran smk wikarya karanganyar tahun ajaran 2014/2015. Jurnal Informasi Dan Komunikasi Administrasi Perkantoran, 1(1), 131-145. Retrieved from http://jurnal.fkip.uns.ac.id.

Yasir, M., \& Ibrahim, M. (2011). Pengembangan perangkat pembelajaran biologi berbasis metakognitif untuk melatihkan keterampilan berpikir reflektif siswa SMA. Jurnal Pengajaran MIPA, $20 \quad$ (2), 163-176. https://doi.org/http://dx.doi.org/10 .18269/jpmipa.v20i2.580. 